\title{
Study on Mesozoic cap rocks and the combination of reservoirs and cap rocks in the South Yellow Sea Basin, China
}

\author{
Jie Liang ${ }^{1,2,3, a}$, Jianwen Chen ${ }^{2,3}$, Penghui Zhang ${ }^{2,3}$, Yinguo Zhang ${ }^{2,3}$, \\ Jianqiang Wang ${ }^{2,3}$ \\ ${ }^{1}$ College of Marine Geosciences, Ocean University of China, Qingdao 266100, China \\ ${ }^{2}$ Key Laboratory of Marine Hydrocarbon Resources and Environmental Geology, Ministry of Land \\ and Resources, Qingdao Institute of Marine Geology, Qingdao, 266071, China \\ ${ }^{3}$ Laboratory for Marine Mineral Resources, Qingdao National Laboratory for Marine Science and \\ Technology, Qingdao 266071, China \\ alj_100@163.com
}

Keywords: Cap rocks, Mesozoic, reservoirs, South Yellow Sea Basin

Abstract. The Mesozoic-Paleozoic marine strata in the South Yellow Sea Basin have been regarded as the new targets for hydrocarbon exploration. In order to carry out the oil and gas resource evaluation in the Mesozoic strata, the condition of the cap rocks and the combination of reservoirs and cap rocks should be carefully analyzed. Whether the combination in the basin is good or not plays a key role in the Mesozoic hydrocarbon preservation. In view of the analysis of structure, stratigraphy and sedimentology in the basin and its adjacent area, Qinglong argillaceous limestones and Cretaceous lacustrine mudstones are regarded as the cap rocks. Adding the distribution pattern of the potential Qinglong Formation reservoirs, the central-eastern part of the Yantai depression has been treated as the most favorable area for the combination of reservoirs and cap rocks.

\section{Introduction}

The South Yellow Sea Basin is a large hydrocarbon-bearing sedimentary basin in eastern China. Up to now, however, commercial volumes of oil and gas have not been found in this basin through geological investigation and exploration activities over more than 50 years. Preliminary work on the petroleum geological conditions has focused on the Cenozoic strata of the Basin. However, failure of the hydrocarbon production activities in the Cenozoic strata have made geologist to pay more attention to the Mesozoic-Paleozoic marine strata in the past decades. With the aid of theoretic simulation, physical simulation and offshore task experiment, great hydrocarbon resource potential has been regarded in the Mesozoic-Paleozoic marine strata [1-4].

Explorations have indicated that the cap rocks controlled hydrocarbon accumulation [5]. The quality of the cap rocks directly affects the formation, scale and preservation of the oil and gas reservoirs [4,6]. However, there is little specific research on cap-rock conditions in the South Yellow Sea basin. In this paper, we analyze the development conditions of the cap rocks and the combination of reservoirs and cap rocks, which provide the basis for Cenozoic-Paleozoic oil and gas resources evaluation in the South Yellow Sea Basin. 


\section{Geological background}

The South Yellow Sea Basin is not only the seaward elongation of the Yangtze Platform, but the main part of the Lower Yangtze Platform. This basin is divided into three structural units: the Yantai depression, the Laoshan uplift, and the Qingdao depression (Fig.1). The marine basin history has basically come to an end to late Early Triassic. The following basin evolution consists Indosinian and Mesozoic foreland basin $\left(\mathrm{T}_{2+3} \sim \mathrm{J}_{1+2}\right)$, basin transitional phase $\left(\mathrm{J}_{3}\right.$ and $\left.\mathrm{K}_{1} \sim \mathrm{K}_{2}\right)$, Cenozoic fault basin (E), and depression period (N) [7]. Marine Cenozoic-Paleozoic strata generally distributes widely. However, thrust faults commonly developed due to strong reworking of Indosinian and Yanshan tectonic movements resulting in strong uplift denudation and fold.

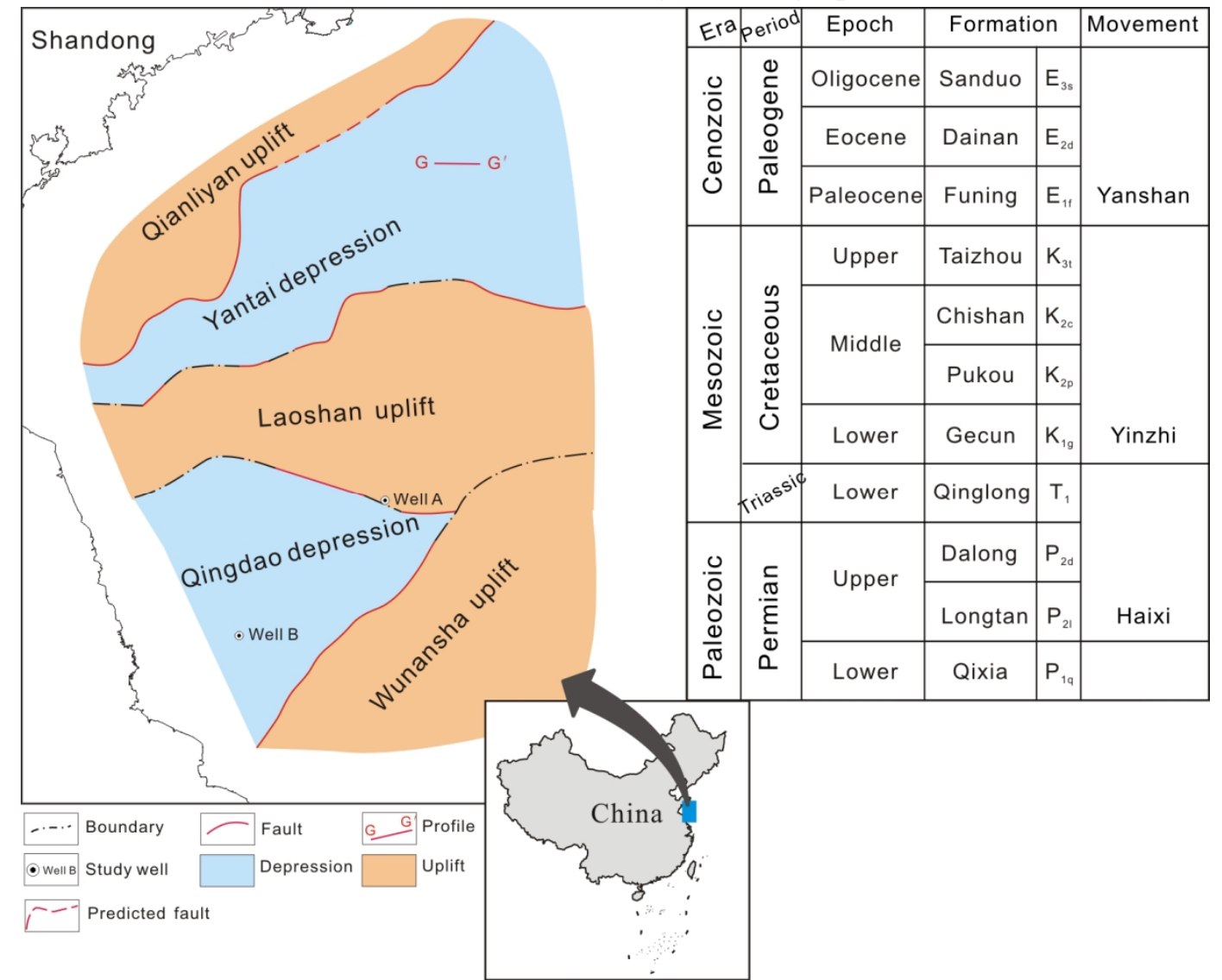

Fig.1 Map showing Mesozoic-Paleozoic tectonic divisions and the Mesozoic stratigraphic correlation in the South Yellow Sea basin

\section{Conditions of the Mesozoic cap rocks}

Cretaceous strata are mainly distributed in the Yantai depression, while it is relatively localized in the Laoshan uplift and the Qingdao depression. The Cretaceous cap rocks are mainly mudstones.

In the Yantai depression, the Cretaceous sedimentary cycle reveals a lake-fluvial-lake phase. Sedimentary thickness of Cretaceous is from 1000 to $2000 \mathrm{~m}$, with a maximum thickness of approximately $4000 \mathrm{~m}$ [4]. The central and northern parts of the Yantai depression are interpreted to have deposited in shallow to semi-deep lacustrine environments, with seismic reflection characteristics of parallel continuous (Fig.2). These thick layers of mudstones can be treated as good cap rocks. In the Laoshan uplift and the Qingdao depression, the localized Cretaceous strata were deposited in fluvial setting, which were supported by the drilling data [4]. The Cretaceous residual thickness is generally between 100 and $300 \mathrm{~m}$, with maximum thickness of around $500 \mathrm{~m}$. These strata cannot be considered as good cap rocks. 


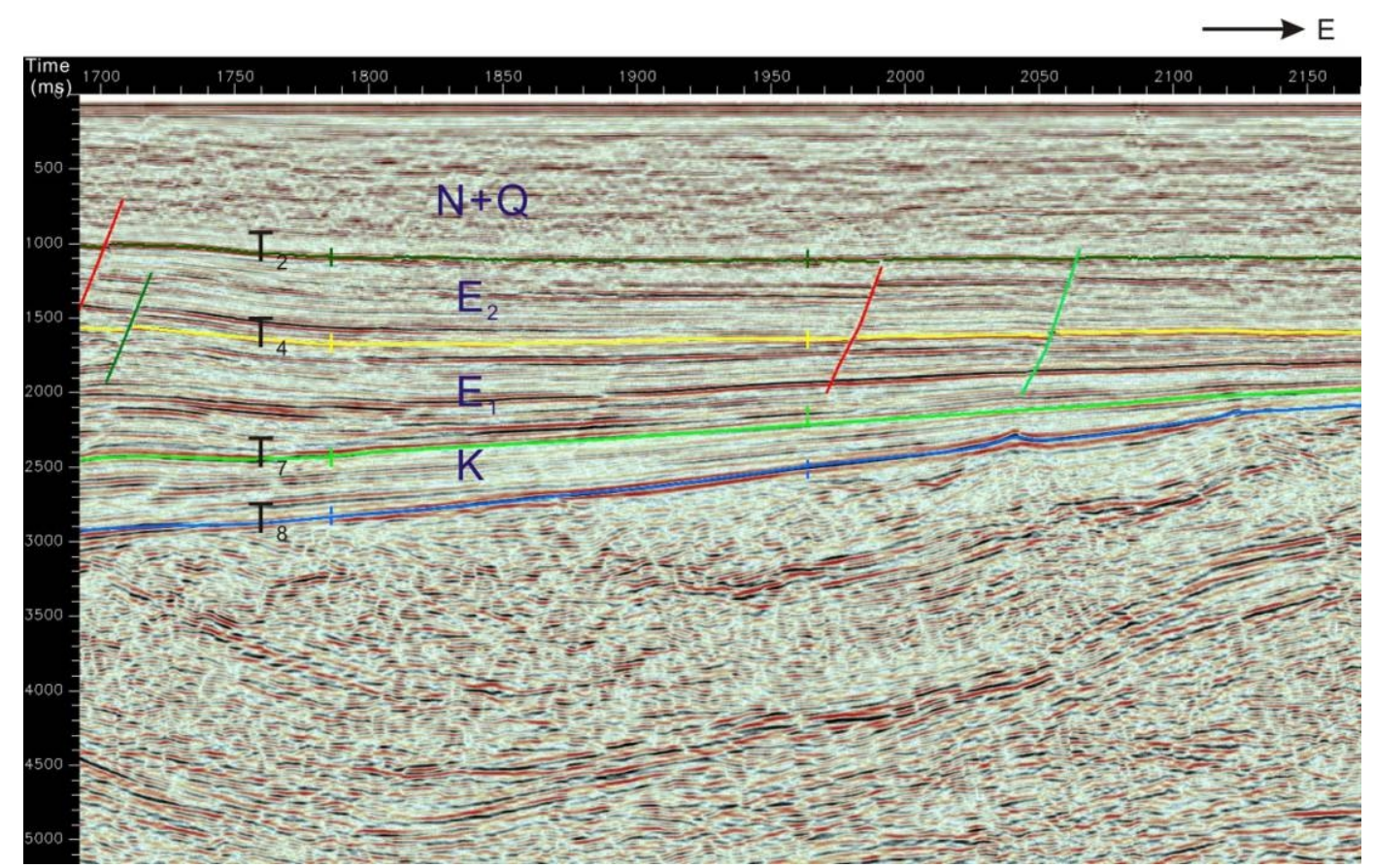

Fig.2 The Cretaceous seismic profile of G-G' line (in Fig.1) in the Yantai depression of the South Yellow Sea Basin

According to the current lithology and paleontology from the drilling data, Qinglong Formation is mainly developed in the Triassic system. Restricted platform, open platform, and slope-shelf depositional settings were identified in the Triassic Qinglong Formation $[4,8,9]$.

The Qinglong Formation in Well A is mainly composed of limestones, with a small quantity of dolomite and argillaceous rocks. The red-brown mudstone interlayer is appeared at the top of the formation. Partial gypsum pseudomorphs can be found in Well A. Carbonate platform deposits are dominant in the Qinglong Formation of Well A.

Thick, continuous mudstones with interbeded marl or thin-layer limestones developed in Well B between 1676 and $2077 \mathrm{~m}$. The total thickness of the mudstones is $207 \mathrm{~m}$. Due to no drilling core from the cap rocks in the South Yellow Sea Basin, displacement pressure measurement cannot be directly used. Instead, estimation of displacement pressure of Qinglong mudstones is about $30 \mathrm{Mpa}$ based on the calculation of acoustic log [4].

For the Qinglong Formation, in general, slope-shelf environment is relatively stable. Mudstones and limestones developed continuously and regionally and were located in the western part of the Qingdao depression, which can be considered as a regional cap rocks. Other regions basically do not have the cap-rock development conditions owing to strong weathering and denudation by the Indian movement and later multi-period tectonic movements.

\section{Combination of reservoirs and cap rocks}

The South Yellow Sea Basin experienced multiple tectonic movements, resulting in great changes in the depositional environments. Multiple sets of sedimentary cycles are conducive to the formation of several sets of combination of reservoirs and cap rocks in the basin.

For Mesozoic strata, dolomite, bioclastic limestones and limestones with fissures in the Triassic Qinglong Formation can be regarded as reservoirs [4]. The corresponding cap rocks are argillaceous limestones in the Qinglong Formation, Cretaceous lacustrine mudstones, and even likely Paleocene Funing mudstones. The most favorable area for the combination is considered to be located in the central-eastern part of the Yantai depression. 


\section{Conclusions}

Mesozoic Cap rocks in the South Yellow Sea Basin mainly consist of Triassic Qinglong argillaceous limestones and Cretaceous lacustrine mudstones. Triassic cap rocks are concentrated on a slope-shelf environment. Cretaceous cap rocks are considered to be deposited in shallow to semi-deep lacustrine environments. Considering the set of combination of reservoirs and cap rocks in Mesozoic strata, Qinglong Formation reservoirs can be treated to be suitable for the combination.

\section{Acknowledgements}

This research was supported financially by the National Special Projects (grant no. XQ-2005-01, 2009GYXQ10, GZH200800503), and the Foundation of Key Laboratory of Marine Petroleum Resources and Environmental Geology, Ministry of Land and Resources (grant no. MRE201415, MRE201114).

\section{References}

[1] Z. Z. Feng, and S. H. Wu: Potential of oil and gas of Qinglong Group lower-middle Triassic in Lower Yangtze river region from the viewpoint of lithofacies Paleogeography. Acta Petrolei Sinica, vol. 9, no. 2 (1988), p.1-8.

[2] X. H. Zhang, D. S. Xu, and J. W. Chen: Geological structure of the Yellow Sea area from regional gravity and magnetic Interpretation. Applied geophysics, vol. 4, no. 2 (2007), p. 75-83.

[3] F. Hu, D. H. Jiang, and X. H. Zhou: Study on the petroleum geologic conditions in Mesozoic-Palaeozoic strata in the South Yellow Sea Basin. Offshore oil, vol. 32, no. 2 (2012), p. $9-15$.

[4] J. Liang, J. W. Chen, Y. G. Zhang, et al: Conditions of the Mesozoic-Paleozoic Cap Rocks in the South Yellow Sea Basin. Geoscience, vol. 30, no. 2 (2016), p. 353-360.

[5] W. Wang, X. H. Yang, J. R. Ye, et al: Ideas and methods of sedimentologic evaluation on caprocks in Zhujiang Formation, Enping Sag. Petroleum Geology \& Experiment, vol. 36, no. 2 (2014), p. 249-256.

[6] Y. S. Yuan, M. Fan, W. X. Liu, et al: T Several discussions of sealing capacity studies of caprock. Petroleum Geology \& Experiment, vol. 33, no. 4 (2011), p. 336-347.

[7] L. Ma, H. J. Chen, K. W. Gan, et al: Geotectonic and Petroleum Geology of Sedimentary Rocks in South China (Geological Press, Beijing 2004).

[8] J. B. Du, M. X. He, Y. X. Zhang, et al: Tectonic evolution and sedimentary characteristics of the foreland basin in the Northern Part of Lower Yangtze. Petroleum Geology and Experiment, vol. 29, no. 2 (2007), p. 134-137.

[9] H. W. Wang, and H. L. Duan: Sedimentary facies of Qinglong Formation in lower Yangtze region. Complex Hydrocarbon Reservoirs, vol. 2, no. 3 (2009), p. 5-10. 